\title{
Evaluation of the religious influence on the feeling of guilt in patients with chronic
}

\section{pain - a review}

\author{
Avaliação da influência religiosa no sentimento de culpa em pacientes com dor crônica - uma \\ revisão
}

Evaluación de la influencia religiosa sobre el sentimiento de culpa en pacientes con dolor crónico una revisión

Caroline Mensor Folchini ORCID: https://orcid.org/0000-0003-2789-3083 Universidade Federal do Paraná, Brazil

E-mail: carol.folchini@gmail.com

Diego da Silva

ORCID: https://orcid.org/0000-0002-6627-3445 UniEnsino Centro Universitário do Paraná, Brazil

E-mail: diegodasilva.psicologia@gmail.com

Eliana Rezende Adami

ORCID: https://orcid.org/0000-0003-3358-0550 Universidade Alto Vale do Rio do Peixe, Brazil E-mail: eliana.rezende@uniarp.edu.br Rosana Claudio Silva Ogoshi

ORCID: https://orcid.org/0000-0003-4383-8236 Universidade Alto Vale do Rio do Peixe, Brazil E-mail: Rosana.ogoshi@uniarp.edu.br

Kátia Regina de Moura Vieira

ORCID: https://orcid.org/0000-0001-5499-3966 Universidade Federal do Paraná, Brazil E-mail:katiakrv@gmail.com

Marcelo Daudt Von Der Heyde ORCID: https://orcid.org/0000-0001-9559-2237 Universidade Federal do Paraná, Brazil E-mail: marceloheyde@yahoo.com

Elcio Juliato Piovesan

ORCID: https://orcid.org/0000-0002-0915-0430 Universidade Federal do Paraná, Brazil E-mail: piovesan1@hotmail.com

Pedro André Kowacs

ORCID: https://orcid.org/0000-0001-7770-7475 Universidade Federal do Paraná, Brazil E-mail: pkowacs@gmail.com

\begin{abstract}
Introduction / Objective: Based on the assumption that pain can be perceived as punishment (pain = penalty), and that this concept of guilt is present in the Judeo-Christian civilization, we decided to review the literature on relevant religious and guilt - which is also a source of suffering - in the management of chronic pain. Methodology. Three searches were carried out that included all articles listed until July 2021 within the PUBMED database. MeshTerm and Boolean operators were used in the following combinations: chronic pain AND religion AND guilt NOT yoga NOT meditation; Chronic pain AND religion NOT yoga NOT meditation; chronic pain AND guilt. Results. Studies carried out in different countries point to the relevance of the chronic relationship of chronic pain to the patient, interfering in a positive way in their evolution, without, however, investigating their relationship with feelings of guilt. Conclusions. The literature is rich in articles on the influence of religiosity in coping with pain, but mentions of feelings of guilt are limited to a single article.
\end{abstract}

Keywords: Chronic pain; Guilt; Religiosity. 


\section{Resumo}

Introdução / Objetivo: Partindo do pressuposto de que a dor pode ser percebida como punição (dor = pena), e que esse conceito de culpa está presente na civilização judaico-cristã, decidimos revisar a literatura sobre religiosidade e culpa relevantes - que é também uma fonte de sofrimento - no manejo da dor crônica. Metodologia. Foram realizadas três buscas que incluíram todos os artigos listados até Julho de 2021 na base de dados PUBMED. Operadores MeshTerm e Booleanos foram usados nas seguintes combinações: dor crônica E religião E culpa NÃO ioga, NÃO meditação; Dor crônica E religião NÃO ioga, NÃO meditação; dor crônica E culpa. Resultados. Estudos realizados em diferentes países apontam para a relevância da relação crônica da dor crônica para o paciente, interferindo de forma positiva em sua evolução, sem, no entanto, investigar sua relação com o sentimento de culpa. Conclusões. A literatura é rica em artigos sobre a influência da religiosidade no enfrentamento da dor, mas as menções aos sentimentos de culpa se limitam a um único artigo.

Palavras-chave: Dor crônica; Culpa; Religiosidade.

\section{Resumen}

Introducción / Objetivo: Partiendo del supuesto de que el dolor puede percibirse como un castigo (dolor $=$ pena), y que este concepto de culpa está presente en la civilización judeocristiana, decidimos revisar la literatura sobre la religión y la culpa relevantes, que es también una fuente de sufrimiento - en el manejo del dolor crónico. Metodología. Se realizaron tres búsquedas que incluyeron todos los artículos listados hasta Julho de 2021 dentro de la base de datos PUBMED. Se utilizaron operadores MeshTerm y booleanos en las siguientes combinaciones: dolor crónico Y religión Y culpa NO yoga NO meditación; Dolor crónico Y religión NO yoga NO meditación; dolor crónico Y culpa. Resultados. Estudios realizados en diferentes países apuntan a la relevancia de la relación crónica del dolor crónico con el paciente, interfiriendo de forma positiva en su evolución, sin, sin embargo, indagar en su relación con los sentimientos de culpa. Conclusiones. La literatura es rica en artículos sobre la influencia de la religiosidad en el afrontamiento del dolor, pero las menciones a los sentimientos de culpa se limitan a un solo artículo.

Palabras clave: Dolor crónico; Culpa; Religiosidad.

\section{Introduction}

Guilt can be defined as an unpleasant or painful feeling, experienced both consciously and unconsciously, which happens at the transgression of some internal or external norm (Bleichmar, 1983). In 1946, Ruth Benedict, who mastered on this field, introduced the anthropological concepts of "cultures of shame". She addressed to this concept making reference to oriental cultures under the influence of Confucius' thoughts and referring to independent Western cultures influenced by Judeo-Christian thinking and focused on self-esteem (Dearing et al., 2005). According to her, "cultures of shame are based on external sanctions for good behavior, not as cultures of guilt, in an internalized conviction of sin. Shame is a reaction to the critical appraisal of other people ... Guilt does not occur this way. In a nation where honor survives thanks to the image that each one makes of himself, a man can suffer guilt without anyone knowing of his fault ... " (Benedict, R, 1989). At this perspective it becomes clear that the sense of guilt should be assessed regarding the cultural context.

There are several ways to interpret human sensation of guilt at experiencing life stressors. In Western society, the notion that a sovereign God rules over life and death, good and evil sets a scenario in which someone facing adversity can find either consolation or punishment in religion. This view is usually taken as a consequence of the weight of the Judeo-Christian influence in Western culture. Consolation occurs whenever there is a meaning for suffering, defined as "positive religious coping". Conversely, when taken as some kind of divine punishment, or even an intervention of evil, it is called negative religious confrontation or coping (Faria \& Seidl, 2005; Mesquita et al, 2013; Panzini \& Bandeira, 2007).

In fact, this sense of punishment may be alive and present in patients with chronic pain. The very term "pain" (Harper, 2001), in the Old French "peine", in turn of the Latin "poena" (Lewis et al., 1979) carries within itself the meaning of punishment (Liddell, 1894). It is expected that an individual will use different strategies to face his suffering, both physical, represented by pain itself and emotional, expressed by guilt arising from the feeling of being punished or, in any way, wronged. Among such strategies, positive or negative religious confrontation may emerge. This, as we have seen, may or may not result in the expected relief. 
The present study aims, through a systematic review of the literature, to find and summarize reports on relationships between pain, guilt and religious beliefs in individuals with chronic pain.

\section{Methodology}

This is a systematic review of the Pubmed databases, concerning empirical studies on the relationship between guilt and religious beliefs in patients with chronic pain. Three different searches were carried out, which encompassed all the archives until July 2021 within the researched database. MeshTerm and Boolean operators were used in the following combinations: 1) chronic pain AND religion AND guilt NOT yoga NOT meditation (0 article); 2) chronic pain AND religion NOT yoga NOT meditation (22 articles); 3) chronic pain AND guilt (1 article). Inclusion criteria were: (a) language: English, Portuguese and Spanish, (b) studies on the quality of the instruments used; Exclusion criteria were: (a) letter to the editor, (b) study addressing meditation, yoga for not being the object of this study.

\section{Results and Discussion}

The abstracts of all articles were analyzed by two of the authors. The search resulted in a total of 23 articles. No articles that included chronic pain, religion and guilt were found (1st search). In a second search, on chronic pain and religion, 22 papers were found. Thirteen of those 22 papers were excluded because they dealt with coping strategies other than religion, and therefore only one study of the third search fulfilled the inclusion criteria was included. The ten papers included were read in full and grouped according to the type of study: validation of an instrument $(n=2)$, observational transverse ( $\mathrm{n}=5$ ), observational longitudinal cohort $(n=1)$ and review $(n=2)$. Details of the selected papers can be appreciated in the Table 1 .

Table 1: features of the literature on guilt and religion in individual with chronic pain.

\begin{tabular}{|l|l|}
\hline Studies & Type of studies \\
\hline Matteliano D, et al (2014) & Scale Validation \\
\hline Taylor LEV, et al (2013) & Scale Validation \\
\hline Lago-Rizzardi CD, et al (2014) & Transverse study \\
\hline Dezutter J, et al (2011) & Transverse study \\
\hline Sooksawat A, et al (2013) & Transverse study \\
\hline Ferreira K, et al (2012) & Transverse study \\
\hline Turner-Coob JM et al (2015) & Transverse study \\
\hline Basiński A, et al (2013) & Cohort study \\
\hline Brangman SA, et al (2015) & Cohort study \\
\hline Stewart WC, et al (2013) & Review \\
\hline
\end{tabular}

Reference: Authors (2021).

According to the American Academy of Pain Medicine 2012, 10 million Americans suffer from chronic pain. "This problem is exacerbated by the lack of consideration of complex biological interaction with psychological, social, and spiritual issues involved in such cases (Drake, 2003).

In a study that aimed to include the spiritual approach in the Biopsychosocial Model, to mitigate the risk of opioid abuse among patients with chronic pain, the authors emphasized the relevance for professionals of being aware that these conditions usually present with symptoms of depression, anxiety, as well as spiritual distress. (Matteliano et al., 2014)

In a proposal of adaptation to the Biopsychosocial Model (BPS), for adults with chronic pain secondary to sickle-cell disease, the authors concluded on the need for an approach of spirituality as a separate dimension within the BPS model of chronic pain. This conclusion was based on their perception of an intersection between the spiritual, psychological and sociocultural dimensions of chronic pain in individuals with sickle-cell disease. (Taylor et al., 2013). 
Current interpretations suggest that spirituality is perceived by patients as an important part of their lives (Yates et al., 1981). In a survey of non-cancer-related chronic pain patients, the presence of spirituality or religious faith was associated with a decreased risk of chronic pain (Rashiq, \& Dick, 2009). In assessing the integration between conventional medicine and spiritual medicine for pain management in African-American patients, their religious beliefs were found to play a relevant role in their comfort (Booker, 2015).

There are several faith-based studies that aimed to understand the impact of religion on patients' lives and illnesses. Most of these studies concluded that in patients who have religious practices interact with God about their state of health benefit from this spiritual interaction, in a way that it brings comfort, increase their knowledge about the disease and compliance to treatment, further improving their quality of life (Stewart et al., 2013).

Two cross-sectional studies with patients with chronic orofacial pain for at least 6 months found spirituality to be an important tool for these patients, and that the habit of praying is associated with a greater tolerance to pain (Lago-Rizzardi et al., 2014; Dezutter et al., 2011).

A cohort study aimed at evaluating the influence of religious practices on quality of life and the subjective level of pain in patients with chronic pancreatitis. The efficacy of pain management was satisfactory both in those patients who did not maintain contact with a church or whose contact was only sporadic as in those who declared religiosity and / or church attendance. Curiously, reported pain levels were higher in patients of higher religiosity and / or church attendance than in the rest (Basiński et al., 2013).

However there are studies that show us another perspective. Of 71 patients with advanced cancer who presented chronic pain, it was observed that those more religious showed lower levels of pain (Yates et al., 1981). The binomial "greater religiosity and lesser pain" was also demonstrated in an analysis of 50 patients with chronic pain, based on the following parameters: church visit frequency, prayer frequency and internal conviction of religiosity. In this study, there was a strong correlation between church attendance - at least once a week - with pain reduction (Harrison et al., 2005).

A cross-sectional study was carried out at the Pain Unit of Maputo Central Hospital, Mozambique, with the objective of describing and analyzing the epidemiological and emotional aspects and religious practices of patients with chronic pain over 18 years of age, according to the IASP criteria. Data previously published for patients with chronic pain, whose predominance occurs among women, with a prevalence in the average age group of 52 years. The main pains corresponded to musculoskeletal and neuropathic pain. It was also observed that religions functioned as a set of beliefs and practices which justified the causes of illness and reestablished the hope of solving problems, making a relation with the painful phenomenon and alleviating the anguish related to it (Ferreira et al., 2013).

Carriers of chronic diseases from various care units were studied in Germany to see if they believed in angels as a coping strategy for their illness. Approximately half of the patients demonstrated belief in guardian angels, even among those who declare themselves to be atheists, evidencing the use of Non-rational strategies in the face of a worsening of their conditions (Büssing et al., 2015).

An observational study, with 63 patients diagnosed with musculoskeletal pain (chronic back pain and sciatica) and 64 controls, explored the prevalence and experience of self-conscious emotions in patients with chronic pain compared to controls, as well as the relationship between Self-conscious emotions and disability in patients with chronic pain. As a result, patients with chronic pain had significantly higher rates of shame, guilt, fear and feeling of defeat when compared to controls. They also noted the importance of future work to offer and deepen from a perspective Beneficial in understanding and managing chronic pain.

Regarding another aspect of our systematic review of guilt feelings in patients with chronic pain, we found a single 
article in which the authors sought a correlation between prevalence and experience of self-conscious emotions, including shame, guilt, humiliation and embarrassment, in patients with chronic low back pain compared to controls Normal. This study revealed that significantly higher levels of shame, guilt, fear of negative assessment and mental defeat in patients with chronic low back pain compared to controls (Turner-Cobb et al., 2015).

\section{Conclusion}

In our opinion it is relevant to search for ways of approaching the feelings of guilt in patients with chronic pain. There is not much medical research in this field of knowledge, perhaps "an avenue" to be explored in the search for coping strategies and maneuvers to ameliorate the suffering of these patients. Throughout this review, no article correlating religiosity with guilt feelings in patients with chronic pain was found, but twelve out of the thirteen papers found a positive correlation between religiosity and a better coping of pain, reflecting the relevance of this influence. No paper encompassing interactions of the biological, psychological, social and spiritual aspects was found. Modern medicine, based on scientific experimentation, tends to ignore or even devalue religious approaches for handling patients' problems. Our review suggests that this type of positioning on the part of health professionals should be discouraged, and in this sense, we agree with Turner-Coobet et al that patient's feelings of guilt should be better detailed and relieved.

\section{References}

Basiński, A., Stefaniak, T., Stadnyk, M., Sheikh, A., \& Vingerhoets, A. J. (2013). Influence of religiosity on the quality of life and on pain intensity in chronic pancreatitis patients after neurolytic celiac plexus block: Case-controlled study. Journal of religion and health, 52(1), 276-284. 10.1007/s10943-011-9454-z.

Benedict, R. (1989). The Chrysanthemum and the Sword. 1946. Cleveland: Meridian.

Bleichmar, H. (1983). Depressão: um estudo psicanalítico. In Depressão: um estudo psicanalítico. Artes Médicas.

Booker, S. Q. (2015). Older African Americans' beliefs about pain, biomedicine, and spiritual medicine. Journal of Christian Nursing, 32(3), 148-155. 10.1097/CNJ.0000000000000152.

Büssing, A., Reiser, F., Michalsen, A., Zahn, A., \& Baumann, K. (2015). Do Patients with Chronic Pain Diseases Believe in Guardian Angels: Even in a Secular Society? A Cross-Sectional Study Among German Patients with Chronic Diseases. Journal of religion and health, 54(1), 76-86.10.1007/s10943-0139735-9.

Dearing, R. L., Stuewig, J., \& Tangney, J. P. (2005). On the importance of distinguishing shame from guilt: Relations to problematic alcohol and drug use. Addictive behaviors, 30(7), 1392-1404. 10.1016/j.addbeh.2005.02.002.

Dezutter, J., Wachholtz, A., \& Corveleyn, J. (2011). Prayer and pain: the mediating role of positive re-appraisal. Journal of behavioral medicine, 34(6), 542549. 10.1007/s10865-011-9348-2.

Drake, R. (2003). Dual diagnosis and integrated treatment of mental illness and substance abuse disorder. Psychiatric Services, 41, $328-335$.

Faria, J. B. D., \& Seidl, E. M. F. (2005). Religiosidade e enfrentamento em contextos de saúde e doença: revisão da literatura. Psicol. reflex. crit, 18(3), 381389. 10.1590/S0102-79722005000300012.

Ferreira, K., Schwalbach, M. T., Schwalbach, J., \& Speciali, J. (2013). Chronic pain in Maputo, Mozambique: new insights. Pain Medicine, 14(4), 551-553. 10.1111/j.1526-4637.2012.01429.x.

Harrison, M. O., Edwards, C. L., Koenig, H. G., Bosworth, H. B., Decastro, L., \& Wood, M. (2005). Religiosity/spirituality and pain in patients with sickle cell disease. The Journal of nervous and mental disease, 193(4), 250-257. 10.1097/01.nmd.0000158375.73779.50.

Lago-Rizzardi, C. D., de Siqueira, J. T. T., \& de Siqueira, S. R. D. (2014). Spirituality of Chronic Orofacial Pain Patients: Case-Control Study. Journal of religion and health, 53(4), 1236-1248. 10.1007/s10943-013-9768-0.

Matteliano, D., Marie, B. J. S., Oliver, J., \& Coggins, C. (2014). Adherence monitoring with chronic opioid therapy for persistent pain: A biopsychosocialspiritual approach to mitigate risk. Pain Management Nursing, 15(1), 391-405. 10.1016/j.pmn.2012.08.008.

Mesquita, A. C., Chaves, É. D. C. L., Avelino, C. C. V., Nogueira, D. A., Panzini, R. G., \& de Carvalho, E. C. (2013). A utilização do enfrentamento religioso/espiritual por pacientes com câncer em tratamento quimioterápico. Revista Latino-Americana de Enfermagem, 21(2), 539-545. 10.1590/S010411692013000200010

^ pain, Harper, D. (2001). Online etymology dictionary. 
Research, Society and Development, v. 10, n. 17, e64101724008, 2021 (CC BY 4.0) | ISSN 2525-3409 | DOI: http://dx.doi.org/10.33448/rsd-v10i17.24008

Panzini, R. G., \& Bandeira, D. R. (2007). Spiritual/religious coping. Archives of Clinical Psychiatry (São Paulo), 34, 126-135. 10.1590/S010160832007000700016.

^ poena, Lewis Charlton, T., Short, C., \& Andrews, E. A. (1879). A Latin dictionary, in Perseus Digital Library.

Rashiq, S., \& Dick, B. D. (2009). Factors associated with chronic noncancer pain in the Canadian population. Pain Research and Management, 14(6), 454460. $10.1155 / 2009 / 919628$

Stewart, W. C., Adams, M. P., Stewart, J. A., \& Nelson, L. A. (2013). Review of clinical medicine and religious practice. Journal of religion and health, 52(1), 91-106. 10.1007/s10943-012-9578-9.

Sooksawat, A., Janwantanakul, P., Tencomnao, T., \& Pensri, P. (2013). Are religious beliefs and practices of Buddhism associated with disability and salivary cortisol in office workers with chronic low back pain? BMC musculoskeletal disorders, 14(1), 29. 10.1186/1471-2474-14-29.

Taylor, L. E. V., Stotts, N. A., Humphreys, J., Treadwell, M. J., \& Miaskowski, C. (2013). A biopsychosocial-spiritual model of chronic pain in adults with sickle cell disease. Pain Management Nursing, 14(4), 287-301. 10.1016/j.pmn.2011.06.003.

Turner-Cobb, J. M., Michalaki, M., \& Osborn, M. (2015). Self-conscious emotions in patients suffering from chronic musculoskeletal pain: A brief report. Psychology \& health, 30(4), 495-501. 10.1080/08870446.2014.991735.

Vertzman, J. Vergonha, honra e contemporaneidade / Shame, honor and contemporary society (2005). revista de psicanálise, 18(181):88-99.

Yates, J. W., Chalmer, B. J., James, P. S., Follansbee, M., \& McKegney, F. P. (1981). Religion in patients with advanced cancer. Pediatric Blood \& Cancer, 9(2), 121-128. 10.1002/mpo.2950090204. 